\title{
An Investigation of the Difficulties Faced by EFL Undergraduates in Speaking Skills
}

\author{
Dina A. Al-Jamal ${ }^{1} \&$ Ghadeer A. Al-Jamal ${ }^{2}$ \\ ${ }^{1}$ Faculty of Education, Yarmouk University, Jordan \\ ${ }^{2}$ King Abdullah Schools for Excellence, Irbid, Jordan \\ Correspondence: Dina A. Al-Jamal, Faculty of Education, Yarmouk University, Jordan. E-mail: \\ deena.j@yu.edu.jo \\ Received: September 29, 2013 Accepted: October 23, 2013 Online Published: December 5, 2013 \\ doi:10.5539/elt.v7n1p19 URL: http://dx.doi.org/10.5539/elt.v7n1p19
}

\begin{abstract}
Since speaking well in English is crucial for English language literature undergraduates, the present study aimed at describing difficulties that may be encountered at an EFL setting. The sample was stratified random as drawn from six Jordanian public universities. Survey questionnaires as well as semi-structured interviews were constructed. 64 students were interviewed out of 566 students who responded to a survey questionnaire. The findings of the study exposed a perceived failure of EFL students' speaking skill in English was reported together with reasons that explain such perceived difficulty. The results of the study showed a 'low' speaking proficiency level among EFL undergraduates along with negligible instruction of the speaking skill at university courses' level. More highlighted difficulties by this study were as these of: communication in L1, large classes, and lack of time.
\end{abstract}

Keywords: EFL, difficulties, Jordanian undergraduates, speaking skill

\section{Introduction}

One of the main arguments in Jordanian EFL education is over student needs; do Jordanians really need to speak English? No country can have a lively culture without working successfully in English. Regardless of the recognition of English by the Jordanian public in general where English is counted as a major subject in the national curriculum, numerous researchers highlighted 'low' achievement scores in English. For a long time, EFL Jordanian students seemed as "confused" by what is perceived as a failure (Abu Sirhan, 2003; Alkhawaldeh, 2005; AL-Momani, 1998; Al-Sobh Al-Abed Al-Haq, 2012; Jafar, 2012).

To learn, EFL learners need to "construct" their own knowledge by understanding through many channels: reading, listening, writing and speaking. Such mode of learning is called 'constructivism' where learning is based on learner's active contribution in successful communication which needs the mastery of several competencies such as: i) linguistic competence that entails knowing grammatical rules (Chomsky, 1965); ii) sociolinguistic competence that means knowing the interpretation of meaning in different language contexts (Hymes, 1972); iii) functional or rhetorical competence that entails mastery of producing messages that relevant to achieve personal goals (Lambert \& Gillespie, 1994). It is vital for students in the 21 st century to learn English communication skills in order to stimulate additional Jordan's growth. The concern of the present research, however, is simply to tackle the speaking 'construct' of students' overall competencies.

Research concluded that student's attitude is an integral part of learning and an essential component of second language learning pedagogy. Psychological theories on attitudes such as Krashen's Affective Filter Hypothesis specified that people acquire second languages only if they attain comprehensible input and if their affective filters are low enough to let the input "in". In his theory, 'affect' includes motivation, attitude, anxiety, and self-confidence. Stern (1983) stated that the 'affective' constituent contributes at least as much, and often more, to language learning than the cognitive skills. Brown (1994: 134) stressed that "Cognitive theories of learning will be rejected unless a role is assigned to affectivity". Therefore, the current study embarked on the importance of EFL attitude and motive as essential in learning a foreign language all through themes relevant to difficulties in speaking skills' delivery.

Such emphasis was placed on the grounds that positive attitude among learners toward speaking a foreign 
language, and genuine beliefs about learning a foreign language may increase the learners' motivation (Sunnarborg, 2002; AL-Wreikat \& Bin Abdullah, 2010).To speak another language, the learner, driven by one or more reasons, has to take the decision why and how. These reasons vary according to optional personal needs for acquiring a second or foreign language. The social psychological components of attitude and motivation are supposed to be significant on language learning success, yet with an indirect relationship between attitude and successful second language learning (Brown, 1994; Freeman, 1991; Littlejohn, 2001)

The present research advocates the innovativeness brought by 'affective' factors impacted widely experimental language-teaching methods. In such approaches, communicative competencies can be developed by employing authenticity, real-world simulation, and meaningful tasks (Brown, 2000). Wilkins's (1999) gave an account of the communicative meanings that a language learner needs to express by establishing the systems of meanings that stand behind the communicative uses of language. The work came to be referred to as the Communicative Approach, or simply Communicative Language Teaching.

Communication is a part of individual life as well as institutional existence. Stryker and Leaver (1997) stated that communication is very much similar to learning to ride a bike or learning to play an instrument. Despite the fact it is generally known that the best mode to learn these skills is by doing them, and not by just studying them or doing exercises and drills, (p. 1). It is generally known that language is most effectively learned in when contextualized. Content-Based Instruction (CBI) refers to an approach to second/foreign language teaching in which teaching is organized around content or information rather than around forms, functions, situations or skills. In CBI, learners are offered meaningful target language content (Stoller, 2004; Nunan, 1999). Accordingly, the present study assumes that "communication" in class where meaningful 'tasks' are given to students is the 'exclusive' method for creating competent EFL speakers, if not adopted many difficulties may, in turn, turn up.

Problem: Although educators now know a great deal about the significance of providing explicit instruction in speaking skill through communicative tasks, little is known about how EFL undergraduates currently learn this particular skill at Jordanian universities. The purpose of this study, hence, was to determine the extent to which and in what ways the promotion and delivery of the speaking skill in class is challenging. In Jordan, English is taught as a foreign language. Although the Jordanian curriculum aims at developing all language skills, nevertheless abundant published studies shows that Jordanian EFL learners come across problems and difficulties in all language skills (Al-Qatawneh 2005; Alkhayyat, 2009; Al-Sobh, \& Al-Abed Al-Haq, 2012; Jafar, 2012; Rababah, 2005).

To grasp that issue fully, perceptions towards such skill together with perceptions regarding the role of English department courses should be identified. The current research, thus, aims to pinpoint a variety of perspectives on matters related to problems and difficulties in the learning of speaking skill in order to contribute to a fuller EFL education as held by the majority of EFL students in Jordan. Explicitly, two research questions guided this study:

1) How do undergraduate students view EFL speaking skill at Jordanian universities' EFL education?

2) Do students' perspectives vary according to the variable of "University" in considering speaking skills as critical in Jordanian universities EFL education?

How are problems built in EFL oral education? This study established a communicative perspective to understand the nature of oral problems in foreign language learning and communication, a viewpoint which delivers a means of being more familiar with the difficulties of problem-construction in EFL oral communication. The current study's contribution to the field was through employing a systematic approach to go deeper in understanding the nature of problem-constructing process in oral instruction at a large scale survey basis. Issues stressed by this research may become 'inputs' for the creating meaning and responding practice where communicators possibly are faced with difficulties in self-expression and understanding of others to deliver their meaning in an awkward and fake L2 context. The current research aims to investigate difficulties of EFL students' oral skills as they major in English language and literature at Jordanian public Universities; how well these English language departments have tackled students' speaking kill, and to assess the reasons why the departments' syllabuses have or have not been executed effectively, by exploring how the skill of speaking operates by different groups who are studying English as a foreign language.

\section{Method}

The proceeding sections have focused on the theoretical and contextual aspect of the study as a whole. This section describes the research design, participants, and data collection procedures. The aim of the current study was to present, as well as to assess, the difficulties in speaking skill success through highlighting the role of English language departments across Jordanian Universities. Based on the theoretical frameworks and research 
discussed earlier, speaking competency could provide a particularly rich opportunity to develop language and social skills. Interviews as well as a survey questionnaire were the means for collecting data for the current study It is hoped that the suggestions of the study to be highlighted as points of departure, rather than arrival, and that they might serve as useful topics for discussion when teaching the skill of speaking at university setting.

The questionnaire was used as a significant instrument in the collection of data for this study. If it is well built, a questionnaire can deliver data economically for it accounts for the scale of the study. Robson (1997) showed that the design of self-completed questionnaires for surveys is likely to have advantages as being of low cost to collect data which could be collected from a large number of respondents. Also, self-completion questionnaire can be cheaper with regard to data processing. In addition, many data can be collected by means of a single questionnaire as well as it produces straightforward descriptive information.

In contrast, there are two main advantages of interviewing (Drever, 1995). The first is that the interviewer can get evidence, stimulate judgment and discuss ideas. The second is linked with its flexibility, so that if the interviewer encounters a difficulty of misunderstanding, s/he can inquire further explanation.

\subsection{Participants}

The whole population of this study is composed of years 1 to 4 EFL students at public universities in different parts of Jordan. Stratified random sampling technique was adopted in the current research. This type is considered less complicated and less expensive (Cohen, Manion, \& Morrison, 2007). The researcher has opted for the probability for selecting students at Jordanian Universities. There was clear intention that these Universities should be representative of the English Language departments at public Universities in Jordan and within each participating English Language Department; the students should be representative of the broader university population from which they were drawn. The following Table displays the numbers withdrawn from each university as amounting up to 566 students (247 males and 319 females) who voluntarily cooperated in the present study for the survey questionnaire. Sixty-four students from all groups participated in the current study accepted to have face-to-face interview sessions. The interviews were conducted in order to obtain information about the speaking abilities of the two groups of students. To analyze the data, transcripts were made of the interviews; notes were made from the recorded material on the speaking performance. These data were confirmed with those from the survey questionnaire.

Table 1. The distribution of sample according to "University" variable

\begin{tabular}{ll}
\hline University & Number \\
\hline Mu'tah & 47 \\
Jordan University for Science and Technology (JUST) & 77 \\
Al-alBayt & 81 \\
Hashemite & 85 \\
Yarmouk & 105 \\
University of Jordan & 171 \\
\hline
\end{tabular}

*Participants' $N o=566$

All data were examined in order to answer the research questions about students' perception of teaching and learning the skill of speaking: To successfully achieve the objectives of the study, two instruments were developed:

1) A survey questionnaire: it was built in light of points taken from general EFL literature. Likert scales were developed at this stage and attached to appropriate questions.

2) Semi-structured interview: The purpose of the interview was to obtain the students' viewpoint about their competence in second-language speaking performance difficulties' perception as well as their stand of university EFL education with regard to teaching this skill. In order to determine students' listening ability, each student was requested to give responses to the questions raised by means of the survey questionnaire.

In order to test face validity of the instrument, five faculty members of the curricula and Instruction department at Yarmouk, Hashemite, JUST, Mu'tah, and Jordan Universities reviewed the instruments. The team was asked to validate the content of the instrument concerning its instructions and suitability to the objectives of the present 
study. The team's comments and suggestions were studied carefully, and the necessary modifications were made accordingly.

Before using the instrument, a pilot study was carried out. The reliability of the instrument, however, was field tested and refined through the split-half method on a pilot group of 60 students $(10$ students at each University in question) chosen randomly and excluded later from the sample of the study. The participants were asked to fill the survey questionnaire twice within a two-week interval. The instrument was further polished and refined as based on pilot study results. The correlation coefficient was found to be 0.90 which was considered to be appropriate to conduct the current study.

\section{Results and Discussion: Jordanian Dtudents' Perceived Failure}

The current study reported a perceived failure of EFL Jordanian students in learning the speaking skill in English. Following this will highlight reasons that explain the perceived difficulty of Jordanian students to learn English. Moreover, this study reported the potential impact by the variable of "University" in shaping such perceptions regarding EFL oral skill teaching. The following Table, however, displays such perspective.

Table 2. EFL students' perceived failure account

\begin{tabular}{|c|c|c|c|c|c|c|c|c|}
\hline \multirow{2}{*}{$\begin{array}{l}\text { The apparent difficulties in } \\
\text { learning oral skills }\end{array}$} & \multicolumn{2}{|c|}{ S.A \& A. } & \multicolumn{2}{|c|}{ U.D } & \multicolumn{2}{|c|}{ S.D \& D.A } & \multirow{2}{*}{$\begin{array}{l}\text { Mean } \\
\text { scores }\end{array}$} & \multirow[t]{2}{*}{ St. Dev. } \\
\hline & No. & $\%$ & No. & $\%$ & No. & $\%$ & & \\
\hline $\begin{array}{l}\text { My English conversation skill } \\
\text { tends to be poor. }\end{array}$ & 482 & 85.2 & 33 & 5.8 & 51 & 9.0 & 4.22 & 0.96 \\
\hline $\begin{array}{l}\text { Speaking courses tend to be } \\
\text { missing. }\end{array}$ & 392 & 69.2 & 53 & 9.4 & 121 & 21.4 & 3.80 & 1.26 \\
\hline $\begin{array}{llr}\text { Classes are } & \text { so large that } \\
\text { speaking } & \text { cannot } & \text { be } \\
\text { demonstrated. } & & \end{array}$ & 312 & 55.1 & 64 & 11.3 & 190 & 33.6 & 3.29 & 1.27 \\
\hline $\begin{array}{l}\text { Classes don not regularly } \\
\text { focus on speaking. }\end{array}$ & 256 & 45.3 & 58 & 10.2 & 252 & 44.5 & 3.00 & 1.44 \\
\hline $\begin{array}{l}\text { Students are de-motivated } \\
\text { towards speaking. }\end{array}$ & 250 & 44.2 & 21 & 3.7 & 295 & 52.1 & 2.93 & 1.36 \\
\hline $\begin{array}{l}\text { Limited exposure to English } \\
\text { spoken in class. }\end{array}$ & 324 & 57.2 & 35 & 6.2 & 207 & 36.6 & 2.86 & 1.35 \\
\hline $\begin{array}{l}\text { Using Arabic in class is } \\
\text { excessive. }\end{array}$ & 330 & 58.3 & 44 & 7.8 & 192 & 34.0 & 2.67 & 1.32 \\
\hline $\begin{array}{l}\text { Efforts repeatedly employed } \\
\text { by EFL lecturers to teach } \\
\text { lessening are minimal. }\end{array}$ & 332 & 58.7 & 40 & 7.0 & 194 & 34.3 & 2.66 & 1.44 \\
\hline $\begin{array}{l}\text { There is always a time } \\
\text { constraint in English lessons. }\end{array}$ & 415 & 73.3 & 24 & 4.2 & 127 & 22.5 & 2.18 & 1.38 \\
\hline
\end{tabular}

As one can see, the highest means of EFL students' responses was that of 4.22. The analysis of the data showed that the majority of the respondents (85.2 per cent) agreed or strongly agreed that My English conversation skill tends to be poor. Perceiving oral performance as minimal reflects how Jordanian undergraduates possess low confidence level in their ability to speak well in English. When students are encouraged to speak in class, this will indirectly promote language acquisition. For speaking, engaging in conversation inspires intake. "Eavesdropping" as F. Schumann and J. Schumann (1977) termed. This may offer the acquirer with an assured volume of intake, but real conversation, in which the acquirer has at least certain control of the topic and in which the acquirer's conversational partner. Such perspective as underestimating language skills competence, for example, is an index of EFL total aim accomplishment disappointment.

The majority of students' interviewees supported the results obtained from the survey questionnaire. In this regards a student participating in the study commented: We've been taught to have consciousness of grammar as 
to remember, for example; teachers have been doing wrong things...they concentrate on rules. Another one said:

Before I came to the University, I did not realize the significance of conversations skills ...but when I first came to University I felt the need for communication when tutors lectured in English. At school I was told what to say, but wasn't really told why I should how or why I should say it ... but at University you've been told the wisdom behind it as well.

The findings indicated that most of EFL students participating in the study were quiet unhappy with their language performance which emphasizes linguistic competence only rather than communicative competence. They felt that their universities do not offer courses for teaching speaking. Students in Table 2 showed more reasons as explaining difficulties such as: large class number; no focus on speaking; absence of motivation, and using Arabic. Some students, however, reported that they have been taught how to speak English at home by watching films and listening to music. Around 400 participants seemed to be aware of the need for speaking skill courses since such courses are lacking with a high mean score as that of 3.80. At this point of view, speaking skill courses seem as lacking students' accountability as for fulfilling communicative goals. That is, more than two-third (69.2 per cent) of EFL students supported the statement that they are encountering a lack of courses for teaching speaking. This is may be due to the fact that students perceive English language as communication and not mere rules. So EFL syllabus content must cater for students' communicative needs.

One student commented that: I think the syllabus don't account for our need to speak. And if there're any teaching about speaking. It seems that the students under investigation tend not to be at peace with the content of EFL education.

From Table 2, it can be seen that more than half of the students (55.1 per cent) pointed out that classes are so large that speaking cannot be demonstrated. Yet no decisive statement can be made on the issue of 'regularity' of focusing on speaking in classes; where close numbers of student (256 and 252 respectively) agreed and disagreed on classes don not regularly focus on speaking. Also, the interviewed students stressed the problem of class size when introducing the skill of speaking. One student expressed that:

At the moment I don't think we have really succeeded in dealing with speaking skill courses. I think the reason behind that is the amount of students in classes.

Another Student Commented that:

There is a major problem in the sense that 'speaking' is very absent. Student don't know converse in English; what to say, when to say or how to say... And this is the role of the University to guide students. Unfortunately students nowadays do not don't know how to interact with a native speaker, how to interact with others in English and how to cooperate and understand natives.

All in all, the present study described that EFL students felt their speaking abilities were not adequate to communicate. It was noted that they had little motivation, little proficiency, and were passive. For a considerable number of the students (57.2 per cent) who responded to the survey questionnaire confirmed that there is $a$ limited exposure to English spoken in class. In this regard, one the interviewed student maintained that: We, sometimes, read from English texts. But if it's without English translation of the meaning we ask the tutor about the meaning and he goes over word by word.

What is more, 45.3 per cent of EFL students participating in this study indicated that Using Arabic in class is excessive. From a communicative viewpoint, theoretical and practical knowledge should be integrated in order to demonstrate language effectively. In EFL education, a balance between theory and practice should be maintained. Once Piagetian constructivism' of learning is lacking, one may fail to set example by making words and actions go together is seriously damaging students' oral skill mastery. This is probably one of the reasons that lead to the non-recognition of English language as a way of self-expression. Since students live in a non-speaking English language country there is no persistent need to master English. People acquire second languages only if they obtain comprehensible input (according to the Affective Filter Hypothesis by Krashen).

Arabic language is considered to be one of the major problems facing teaching and learning English. It is true that translation makes it FLL as more accessible and can be understood but still, in order speak English right, one needs to listen and to converse in English rather than in Arabic. Throughout the interviews and when asking students: do you translate any of the English texts? And to what extent do you memorise? A typical response by one interviewed student was: Translation is a very essential. In literature courses, one play is devoted to the translation of most words and phrases... On the other hand, some students in the study perceived using Arabic 'excessively' in EFL classes facilitates learning the foreign language. One of the students said:

When you come to English classes you'll find out they are focusing, you know, on literature things. But when 
professors use Arabic; I can make connections and guess a lot of ideas, phrases and words.

In the present study "interference" was noticed as the result of students" "falling back" on old knowledge when he or she has not yet acquired enough. In terms of the Monitor performance model (Krashen, 2002), interference is the result of the use of the first language as an utterance initiator: first language competence may replace acquired second language competence in the performance model.

Obviously as Table 2 shows, the students' perspective on being motivated towards speaking lacks a regular pattern of response where 250 students felt motivated; whereas 295 students felt demotivated. It is well known for all around the world motivation is crucial in effective EFL education setting EFL education (Alkhayyat, 2009; Brown, 2000; Freeman, 1991; Littlejohn, 2001; Sunnarborg, 2002; Rabab'ah, 2005). In contrast, students' positive aptitude would result in positive attitude towards improving their oral communication ability and aspirations to reach the desired effect.

The lowest mean scores, in Table 2, of students' responses on Efforts repeatedly employed by EFL lecturers to teach lessening are minimal as well as on time constraint in English lessons scored 2.66 and 2.18 respectively. Information obtained from the survey questionnaire, nonetheless, indicated that tutors, nearly, failed to include the speaking skill. The findings reported that tutors play a vital role in teaching the skill of speaking. One student argued that:

I think tutors have a big part in introducing speaking, and change the true idea of communication in English... They give us information in brief... We need something in detail. We need to focus on the skill of speaking.

That is, the existent study reported that EFL students felt their speaking abilities were not adequately developed by their tutors. Even more it was noted that tutors care more for 'pencil and paper' tests rather than 'whole language' test. In a word, proof of test washback was detected all through tutors' teaching practices. Their teaching practices tend to be influenced by aspects of examinations on washback (Alderson \& Hamp, 1996). Washback covers every element affected by tests, from individuals to general society (Caine, 2005, p. 16). Al-Jamal, and Ghady (2008) asserted that test washback damagingly touches the extent of oral English taught in EFL lessons in Jordan. Although English is a fundamental subject school curriculum, yet there is no speaking element present. This may, in turn, lessen both student enthusiasms to EFL oral communicate. Al-Jamal and Ghady stated that most Jordanian high school students study English language as the main reason for passing the exams.

Additionally, the study investigated the role of 'University' variable on students' responses. The following Table displays the findings.

Table 3. The Effect of university variable on students' responses

\begin{tabular}{llllll}
\hline University & Number & Mean rank & Chi-Square & Degree of Freedom & Sig. \\
\hline Mu'tah & 47 & 96.68 & 75.123 & 5 & 0.00 \\
JUST & 77 & 280.49 & & & \\
Al-alBayt & 81 & 279.42 & & & \\
Hashemite & 85 & 328.31 & & & \\
Yarmouk & 105 & 287.98 & & & \\
University of Jordan & 171 & 298.65 & & & \\
\hline
\end{tabular}

*Participants' $\mathrm{No}=566$

The results indicated that there is a statistically significant difference between the participating students, where $\mathrm{P}=0.00$ as estimated by Chi-square (75.123) with 5 degrees of freedom which is less than the significance level (0.05). In order to determine which group means differ significantly from each other, the results of the multiple comparison procedure were computed. Accordingly, the University that scored the highest mean (328.31) was that of Hashemite, then the mean of University of Jordan was that as 298.6. Afterwards the mean of Yarmouk University scored 287.98 , followed by JUST with the mean score of 280.49 , then the mean score of Al-alBayt University is that of 279.42 and finally the mean of 96.68 as scored by participants from Mu'tah University.

Reading through the mean ranks again looks as if Hashemite University tended to be effective as well as successful in delivering speaking s kills if compared to the other Universities. One may argue that students in 
such University tend to be more concerned with the education of English language skills mainly speaking because of syllabus requirement. At the Hashemite University, students study extra two courses on oral skills when compared with other Jordanian Universities. In addition, facilities and equipment are available at the Hashemite University, so unlike other Universities which facilitate the teaching/learning process.

\section{Conclusion}

Since communication skills play a dynamic role in effective EFL education, the findings of this study provide an indication that EFL students tend to be inadequately equipped. Overall, the outcomes of the study show that the 566 undergraduate students in the sample possess low self-efficacy perspectives, which means they have low self-confidence in their ability to communicate in English. According to statistics from the study's survey questionnaire, $85.2 \%$ of students perceive their conversational skills as' low', more than two third of the students think that there is a frantic need to teach oral skills at EFL education courses. More than half of the students highlighted the obstacle of large classes, which in turn, will result in not maintaining oral skills instruction. Another considerable number of the students (57.2\%) confirmed the absence of English speaking in class. $45.3 \%$ of students stated that English speaking skill is swapped by communication in Arabic. lecturers variable as well as time variable were perceived as insignificant obstacles in oral skills instruction.

The findings of the study stressed that imparting instruction the speaking skill to EFL undergraduates poses a great challenge to their communicative competence. A very important aspect of the problem that has been highlighted by this study is the need to evaluate the English departments' programmes and curricula to make sure that such curricula and programmes are adequate to cater for the students' communicate needs. The lack of adequate facilities at Jordanian Universities such as laboratories together with large classes seems to be major obstacles to the adequate delivery of the teaching of the speaking skill. Evidence suggests that the time allocated for teaching the speaking skill in classes was insufficient to provide students with communicative activities.

The study showed that EFL undergraduate responses were broadly consistent through the questionnaires as well as through the interviews. The respondents appeared to report in the same way to many issues and concerns regarding the difficulties in speaking skill teaching and learning, which obviously looked to be common in all EFL settings. The findings of the study revealed a number of criticisms of the teaching process of English language subject at the university level. These criticisms include the following: the lack of relevance of the content of textbook to student's daily communicative needs, the excessive focus on descriptive aspects of language while ignoring the real world applied aspects. To which should be added, the difficulty in understanding the content of the syllabus, failure to positive attitudes towards the subject, and giving inadequate importance to the memorisation of rules and vocabulary items.

Reflections obtained by this study are similar to those stated by (Al-Sobh Al-Abed Al-Haq, 2012; Jafar, 2012). English speaking skill instruction should be mostly driven by the advancement in considering psychological factors (AL-Wreikat \& Bin Abdullah, 2010; Stern, 1984; Sunnarborg, 2002), especially in 'affective factor' (Brown, 2000; Freeman, 1991; Littlejohn, 2001), Content Based Instruction (Stoller, 2004; Nunan, 1999), sociolinguistic competence (Hymes, 1972). The globalisation of English as an international language has dramatically changed the course of teaching it as a tool for communication that would be a valuable asset to create and sustain thriving relationships which may lead to higher levels of self-efficacy in their oral communication ability in English. If learners would like to be a part of globalization, they must be able to communicate well in English, since it can often aid as the worldwide language between two people from two different cultures, neither of whom speak English as their native tongue. It is consequently very imperative for university students to acquire English and be able to speak the language.

\section{References}

Abu Sirhan, O. E. (2003). English language teachers' use of metacognitive reading comprehension strategies in Jordanian secondary schools. (PhD dissertation, Jordan: Amman Arab University).

Al-Afeef, Mohammad Hamid. (2002). Communicative language teaching in the upper basic grades in Jerash district: A teachers' perspective. (Unpublished Master thesis, Irbid: Yarmouk University).

Alderson, J. C., \& Hamp-Lyons, L. (1996). TOEFL preparation courses: A study of washback. Language Testing, 13, 280-297. http://dx.doi.org/10.1177/026553229601300304

Al-Jamal, D., \& Ghady, N. (2008). English language general secondary certificate examination washback in Jordan. Asian-EFL Journal, 2(3), 159-187.

Alkhawaldeh, A. H. (2005). Jordanian English language teachers' wareness of Language learning theories and teaching methods. Mu'tah Lil-Buhuth Wad-Dirasat, 20(7). 
Alkhayyat, A. (2009). Measuring EFL Teachers' Knowledge of Communicative Language Teaching Approach and their Practices in the Jordanian Public Schools. Jordan Journal of Educational Sciences, 5(4), 399-415.

AL-Momani, N. (1998). An evaluation of EFL textbooks (AMRA) for the first and second secondary class in Jordan: Student teachers' and supervisors' perspectives. (Unpublished M, Ed, thesis, Jordan, Irbid: Yarmouk University).

Al-Sobh, M. A., \& Al-Abed Al-Haq, F. (2012). Online linguistic messages of the Jordanian secondary students and their opinions toward a web-based writing instructional EFL program. International Journal of Humanities and Social Science, 2(6), 288-299.

Al-Wreikat, Y. A., \& Bin Abdullah, M. K. (2010). An evaluation of Jordanian EFL teachers' in-service training courses teaching techniques effectiveness. English Language Teaching, 3(4), 18-27.

Brown, H. D. (1994). Principles of language learning and teaching. New Jersey: Prentice Hall Inc., Englewood Cliffs.

Brown, H. (2000). Teaching by principles: An interactive approach to language pedagogy. San Francisco, California. A Pearson Education Company.

Caine, N. (2005). EFL Examination Washback in Japan: Investigating the effect of oral assessment on teaching and learning. (MA. thesis, England: The University of Manchester).

Chomsky, N. (1965). Aspects on the theory of syntax. Cambridge, Massachusetts: The MIT.

Louis, C., Manion, L., \& Morrison, K. (2007). Research methods in education (6th ed.). New York: Rutledge.

Drever, E. (1995). Using semi-structured interviews in small-scale research. A teacher's guide. Edinburgh: Scottish Council for Research in Education.

Freeman, D. L. (1991). Second language acquisition research: Staking out the territory. TESOL QUARTERLY, 25(2), 133-168.

Hymes, D. (1972). On communicative competence. In J. B. Pride, \& J. Holmes (Eds.), Sociolinguistics (pp. 269-285). Harmondsworth: Penguin.

Jafar, F. (2012). Attitudes and Motives of Jordanian University Students towards Learning English. Jordan Journal of Educational Sciences, 8(4), 377-385.

Krashen, S. D. (1982). Principles and practices in second language acquisition. Oxford: Pergamon Press.

Krashen, S. D. (1985). The input hypothesis: Issues and implications. New York: Longman.

Krashen, S. (2002). Second language acquisition and second language learning. University of Southern California.

Krashen, S. D. (1987). Principles and practice in second language acquisition. Prentice Hall International.

Lambert, B. L., \& Gillespie, J. L. (1994). Patient perceptions of pharmacy students' hypertension compliance-gaining messages: Effects of message design logic and content themes. Health Communication, 6, 311-325. http://dx.doi.org/10.1207/s15327027hc0604_6

Littlejohn, A. (2001). Motivation, Where does it come from? Where does it go? Karen's Linguistics Issues. Retrieved from http://www3.telus.net/linguisticsissues/motivation.html

Nunan, D. (1999). Second language teaching and learning. Boston: Heinle \& Heinle Publishers.

Piaget, J. (1959). The language and thought of the child (3rd ed.). New York: the Humanities Press Inc. Press.

Rabab'ah, G. (2005). Communication problems facing Arab learners of English. Journal of Language and Learning, 3(1), 180-197.

Roboson, C. (1997). Real world Research: A Resource for Social Scientists and Practioner-Researchers. Oxford: Blackwell.

Schumann, F., \& Schumann, J. (1977). Diary of a language learner: An introspective study of second language learning. In H. D. Brown (Ed.), Teaching by principles: An interactive approach to language pedagogy. San Francisco, California: A Pearson Education Company.

Stern, H. H. (1983). Fundamental concepts of language teaching. Oxford: Oxford University Press.

Stoller, F. (2004). Content-based instruction: Perspectives on curriculum planning. Annual Review of Applied Linguistics, 24, 261-283. U.S.A: Cambridge University Press. 
http://dx.doi.org/10.1017/S0267190504000108

Stryker, S., \& B. Leaver. (Eds.) (1997). Content-based instruction in foreign language education: Models and methods. Washington, D.C.: Georgetown University Press.

Sunnarborg, Peter. (2002). Exploring attitude and attitude change in second language learners, Practicing Thoughtful Inquiry and Reflection. Retrieved from http://sites.hamline.edu

Terrell, T. (1977). A natural approach to second language acquisition and learning. Modern Language Journal, $11,325-337$.

Wilkins, K. G. (1999). Development discourse on gender and communication in strategies for social change. Journal of Communication. Retrieved from http://www.search.ebscohost.com

\section{Copyrights}

Copyright for this article is retained by the author(s), with first publication rights granted to the journal.

This is an open-access article distributed under the terms and conditions of the Creative Commons Attribution license (http://creativecommons.org/licenses/by/3.0/). 